\title{
The Role of IL-17, Metaphase Reactants on Patients with Early Rheumatoid Arthritis disease Activity and Trace Elements
}

\author{
* Wamedh R. Daham**Ass.prof.Dr.Mahal.K.Rasheed, * Dr. Mohammed H \\ Department Biochemistry, College of Medicine, University, Baghdad, Iraq ** \\ Department Biochemistry, College of Medicine ,University, Baghdad, Iraq ** \\ *Lecturer. Al-Osami CABM, FICMS (Rheum\&Med Rehab)College of Medicine, University of Baghdad.
}

\begin{abstract}
Rheumatoid arthritis (RA) represents the most common form of chronic inflammatory joint disease leading to cartilage and bone destruction, It affects approximately 1-2 \% of world's population. The inflammatory process causes diffuse thickening and hyperplasia of the joint Interleukin (IL)-17 is a pleiotropic pro-inflammatory cytokine produced from Th17 cells. IL-17A is the prototypic member belonging to a family of 6 ranging from IL-17A to IL-17F. IL-17A mediates its biological effects through binding to a receptor complex consisting of IL-17RCA and IL-17RCC subunits.

Objective. To assess the role of IL-17 on the disease process of Rheumatoid arthritis and the effects on the trace elements such as Zinc, copper, Magnesium.

Subjects and method: A total of 60 patients with early Rheumatoid Arthritis were studied. Their ages ranged from 20-52 years with a mean age of ( $39.3 \pm 9.01)$ years., while the range was between (20-51) years and the mean was $(37.5 \pm 8.6)$ years for healthy control non significant difference $P>0.4$ with no complaint of other chronic or systemic diseases were considered as control. the samples were collected during period from ( December 2012 - july 2013 ). the mean disease duration of RA was (3.27 \pm 1.2$)$ month. Blood samples were collected from patients and controls to assess Erythrocyte Sedimentation Rate (ESR) and serum levels of White blood cells (WBC), Hemoglobin (Hb), Interleukin-17A and were estimated by agglutination test, and IL-17A was estimated by (ELIZA).

Results .All data are represented as Mean $( \pm S D)$ The mean of Interleukin -17 concentration was $(8.6 \pm 7.6 \mathrm{pg} / \mathrm{ml})$ for patients compared with $(5.3 \pm 3.8 \mathrm{pg} / \mathrm{ml})$ for healthy control group which shows significant difference $(P<$ $0.05)$. Estimation of erythrocyte sedimentation rate (ESR) by westergreen' method. forty-eight patients (80\%) have high level of ESR $\geq 20 \mathrm{~mm} / \mathrm{lhr}$, with highly significant difference $(P<0.0005)$. There was no significant alteration occurs on the mean of WBCs count of early RA patients $(9.4 \pm 2.5) 10 e 3 / u L$ in comparison with healthy control group $(8.5 \pm 2.4) 10 e 3 / u L(P \leq 0.1)$. Moreover, majority of $R A$ patients were anemic. the mean of $\mathrm{Hb}$ is (12.6 \pm 1.7$) \mathrm{gm} / \mathrm{dl}$ for RA patients in comparison with apparently healthy control $(13.8 \pm 1.8) \mathrm{gm} / \mathrm{dl}$ with highly significant differences $(P \leq 0.01$ for each). In this study, the mean serum zinc level was significantly lower in patients $(74.4 \pm 7.1 \mathrm{mg} / \mathrm{L})$. than in healthy controls' $(98.4 \pm 9.1 \mathrm{mg} / \mathrm{L})(p<0.005)$ the serum Copper level was significantly higher in early RA patient (ranges from 137-215 mg/L, mean value $172.1 \pm 19.1 \mathrm{mg} / \mathrm{L}$ ). Than is level in healthy control group (ranges from $105-150 \mathrm{mg} / \mathrm{L}$, mean value $125.1 \pm 11.6 \mathrm{mg} / \mathrm{L}) \quad(p<0.005)$. In patients with early $R A$, the mean level of serum $(M g)$ was significant lower ( $1.2 \pm 0.13 \mathrm{mg} / \mathrm{L})$. as compared with healthy control group mean value $(1.6 \pm 0.19 \mathrm{mg} / \mathrm{L})(\mathrm{p}$ value $<0.0005)$.

Conclusions. Interleukin-17 (IL17A) may has a key role in early Rheumatoid Arthritis inflammatory process. Interleukin-17A was associated with morning stiffness. The results observed that the levels of serum Zinc, Magnesium were significantly low in patients with early Rheumatoid arthritis as compared with healthy control group. In early Rheumatoid arthritis the level of serum Copper was highly increased in the patients.Morning stiffness, joint swelling and fever are the main clinical features (100\%, 85\% and 80\% respectively) which were noticed among $R A$ patients.

Keywords : Interleukin-17A (IL-17A), RA, Trace elements.
\end{abstract}

\section{Introduction.}

Rheumatoid Arthritis (RA) is a chronic disease characterized by synovial inflammation and destruction of joint cartilage and bone mediated by persistent synthesis of pro-inflammatory cytokines and tissue-destructive enzymes, such as matrix metalloproteinase (MMPs), T-cell activation and migration occurs as an early consequence of RA, and these cells adopt a pro-inflammatory phenotype (1). Interleukin (IL)-17 is a pleiotropic pro-inflammatory cytokine produced from Th17 cells. IL-17A is the prototypic member belonging to a family of 6 ranging from IL-17A to IL-17F. IL-17A mediates its biological effects through binding to a receptor complex consisting of IL-17RCA and IL-17RCC subunits. IL-17 may play a critical role in the pathogenesis of RA. It is capable of promoting inflammation by inducing a variety of pro-inflammatory mediators, including cytokines, chemokine's and other mediators of bone and cartilage destruction in synovial 
fibroblasts, monocytes, macrophages and chondrocytes $(2,3)$. The potential importance of IL-17 in RA is supported by the observation that IL-17 is critical for the development of, and is an effective therapeutic target in, a variety of animal models of RA (4). Zinc is a part of every cell in the body and forms a part of over 300 enzymes that have functions ranging from proper action of the body hormones to cell growth. Zinc deficiency can cause growth retardation ( 5,6 ). Zinc is important in the maintenance of proper immune response( 6).Copper is an essential part of key metalloenzymes as ceruluplasmine, cytochrome, oxidase, tyrosinase and monamine oxidase (7). Copper enters in a large number of enzymes in addition ceruloplasmin, as it will be necessary for the work of an enzyme super oxide dismutase (SOD) as well as an oxidation enzyme Lysyl oxidase, which is one of the necessary enzymes in the synthesis of connective tissue, it is believe that lack of this enzyme leads to decrease of Copper, which leads to adverse effects in bone and connective tissue ( 8) . Excess Copper as with excess Iron can cause free radical production and damage, also deficiency of Copper results in poor collagen integrity with resultant blood vessel rupture $(8,9)$. Magnesium is involved in at least 300 enzymatic processes Magnesium participates in a number of biochemical reactions that take place in bone. Alkaline phosphatase, enzyme involved in forming a new calcium crystals, is activated by Magnesium. The conversion of vitamin D to its biologically active form 1,25 dihydroxy vitamin D3 also appears to require Magnesium. Deficiency of Magnesium can produce a syndrome of vitamin D resistance. The concentration of intracellular Magnesium is very high as compared with concentration of extracellular Magnesium for that reason can be attributed the increase in the output cell concentration to the damage done to the cells and then increase its concentration in the blood serum(10)(11). Magnesium an important in bone structure. Deficiency results in tetany and can lead to calcium deficiency. Magnesium is essential to maintain both acid- base balance in the body, and healthy functioning of nerves and muscles(12)Diets that provide recommended levels of Magnesium are beneficial for bone health, but further investigation on the role of Magnesium in bone metabolism and osteoporosis is needed (13).

\section{Materials and methods.}

Sixty patients with early RA (48 females and 12 males ) their ages ranged between (20-52) years, with means \pm SD $(39.3 \pm 9.01)$ years. The mean duration of the disease was (3.2) month. The healthy control group consisted of 20 healthy (15 females and 5 males) individuals with good general health who receive no medication, their ages ranged between (20-51) years, with means $\pm \mathrm{SD},(37.5 \pm 8.6)$. All statistical work and reporting of obtained data were carried out by using SPSS program version 17.0. Difference of the means considered of significance according to the t-test at level of $(p<0.05)$ and $(p<0.01)$. Blood samples were collected from patients and controls to assess Erythrocyte Sedimentation Rate (ESR) and serum levels of White blood cells ( WBC), Hemoglobin (Hb) and were estimated by agglutination test, and Interleukin-17A (IL-17A) was estimated by (ELIZA) . BMI equals to a mathematical formula based on a person's weight by kilograms divided by height in square meter $\left(\mathrm{BMI}=\mathrm{Kg} / \mathrm{m}^{2}\right)$. It was suggested that a BMI of $18.5-24.9 \mathrm{Kg} / \mathrm{m}^{2}$ indicates a person of normal weight, a person with a BMI of $25-29.9 \mathrm{Kg} / \mathrm{m}^{2}$ is overweight, while a person with a BMI of $\geq 30 \mathrm{Kg} / \mathrm{m}^{2}$ is obese [ (Global database on body)World Health Organization. Geneva. 2006].

\section{R e s u l t s.}

The studied groups was with age range between (20-52) years and the mean was $(39.3 \pm 9.01)$ years for early RA patients, while the range was between (20-51) years and the mean was $(37.5 \pm 8.6)$ years for healthy control non significant difference $\mathrm{P}>0.4$. as shown in table(4.1)

Table (4.1): Description of the studied groups .

\begin{tabular}{|ll|l|l|l|}
\hline & Early RA Patients & Healthy Control & \\
\hline Age & Range & $(20-52)$ years & $(20-51)$ years & \\
& Mean & $39.3 \pm 9.01$ & $37.5 \pm 8.6$ & $\mathrm{P}>0.4$ \\
\hline
\end{tabular}

Regarding age groups, the highest rate of incidence of the disease was found in the fourth decade of life ( $23 \%)$, followed by third and fifth decades $(15 \%$ and $12 \%)$, respectively as shown in figure 4.1.Chi-square test showed that there was no significant difference in the frequency of age groups between RA and control group $(\mathrm{P}>0.434)$ 


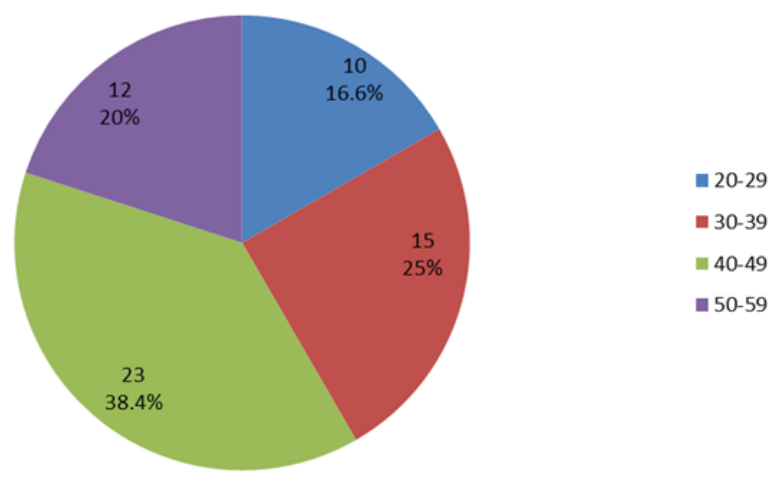

Figure 4.1: Distribution of RA patients according to age groups.

Table 4.2 Furthermore, it is clear that (1-2 month) have been passed for $(8.4 \%)$ of RA cases while it is clear that (2-4 month) have been passed for ( $25 \%)$ of RA cases while only $(66.6 \%)$ of other RA cases have a duration of 4-6 month with higher significant difference in RA ( $\mathrm{P}<0.0005)$.

Table 4.2: Distribution of the studied groups according disease duration

\begin{tabular}{l|l|l|l|l|}
\hline \multirow{2}{*}{ patient group } & \multicolumn{2}{|l|}{ Early Rheumatoid arthritis } & P-value \\
\cline { 3 - 5 } & & No. & $\%$ & \\
\multirow{2}{*}{$\begin{array}{l}\text { Disease } \\
\text { Duration } \\
\text { group } \\
\text { (month) }\end{array}$} & $1-2$ & 5 & 8.4 & 0.000 \\
\cline { 2 - 4 } & $2-4$ & 15 & 25 & HS \\
\cline { 2 - 4 } & $4-6$ & 40 & 66.6 & \\
\cline { 2 - 4 } & Total & 60 & 100 & \\
\hline
\end{tabular}

The demographic parameters of studied group are listed in the table: 4.3 . This table reveals that the majority of RA patients are females [48 out of 60] (80\%) with females: males ratio of 4:1. Moreover, the average of the

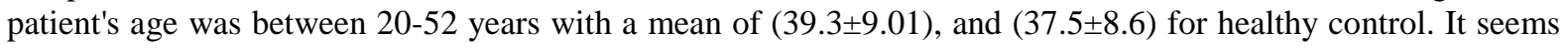
to be that there is no significant difference between RA and control group $(\mathrm{P}<0.422)$. table 4.3 and figure 4.2

Table 4.3: Gender type distribution between early RA patients and healthy controls.

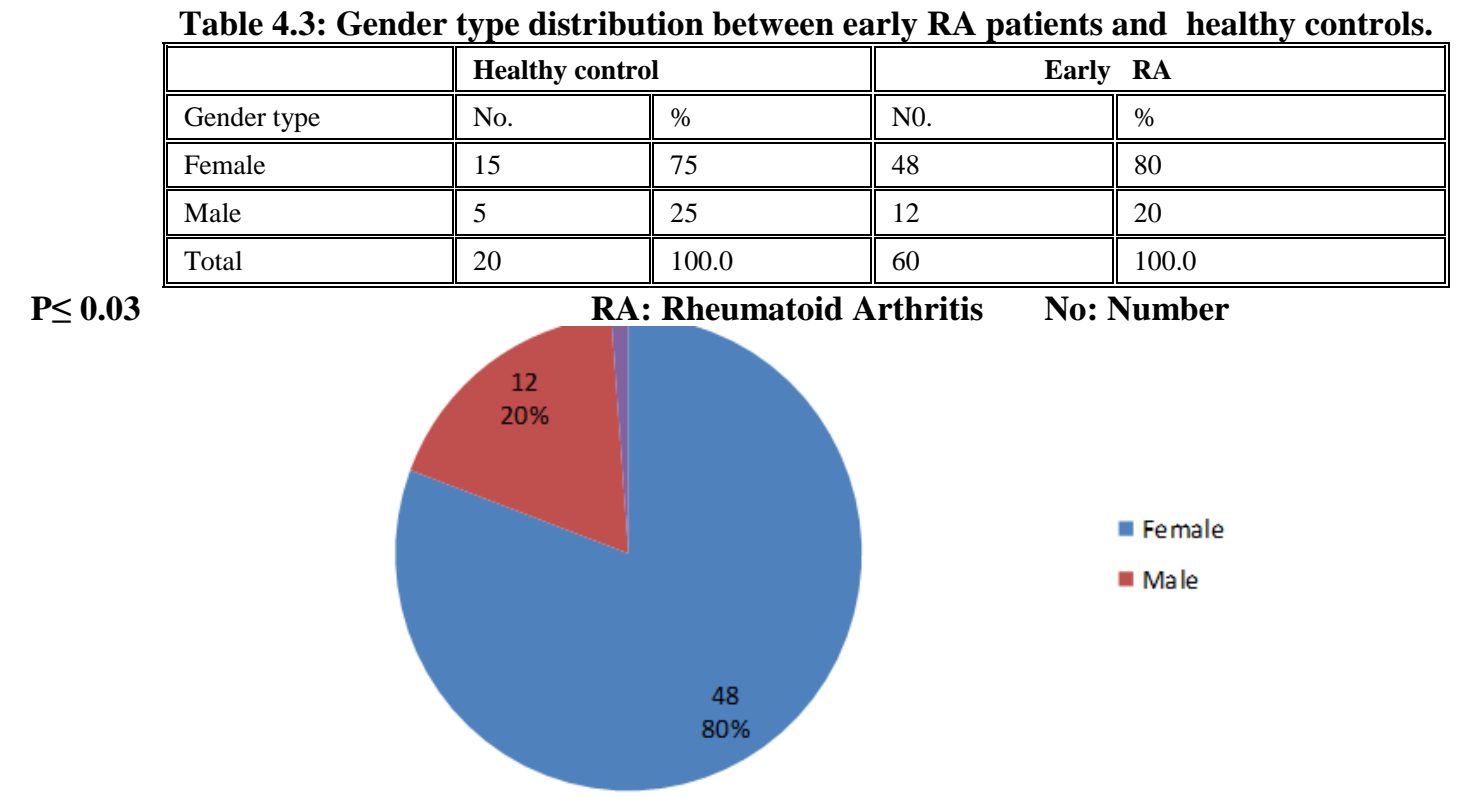

Figure 4.2: Gender type distribution in RA patients.

Regarding BMI, the present study demonstrated that high percentage of RA patients were normal weight $(70 \%)$ followed by $16.6 \%$ were overweight and obese $13.4 \%$. Statistically there was significant differences between healthy control group and RA patients in the frequency of body mass index scores $(\mathrm{P} \leq 0.05)$, table 4.4 and Figure 4.3 
Table 4.4: Descriptive analysis of BMI scores in study groups.

\begin{tabular}{|c|c|c|c|c|}
\hline \multirow{2}{*}{ Body mass index score } & \multicolumn{2}{|c|}{ Healthy control } & \multicolumn{2}{|c|}{ Rheumatoid arthritis patients } \\
\hline & No & $\%$ & No & $\%$ \\
\hline Normal weight & 4 & 20 & 42 & 70 \\
\hline Overweight & 13 & 65 & 10 & 16.6 \\
\hline Obese & 3 & 15 & 8 & 13.4 \\
\hline Total & 20 & 100.0 & 60 & 100.0 \\
\hline
\end{tabular}

$P$ value $\leq 0.05 \quad$ No: Number

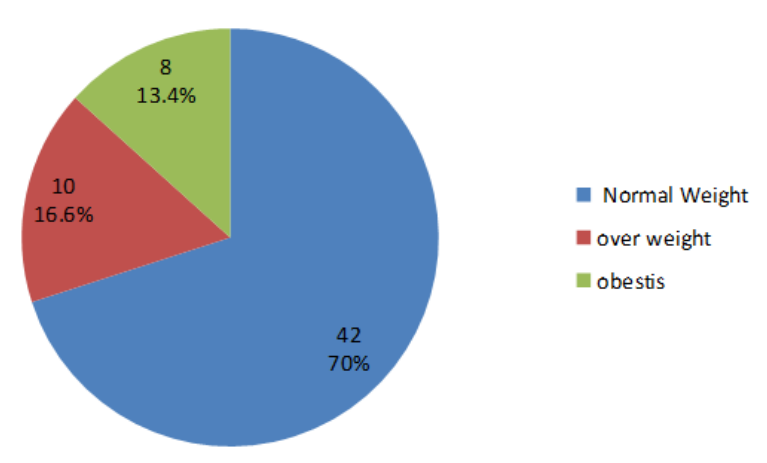

Figure 4.3: Distribution of BMI score among RA patients.

The laboratory results of ESR showed that there was higher value of ESR in RA patients than healthy control group with highly significant difference $(\mathrm{P} \leq 0.0005)$, table 4.5 and Figure 4.4

Table 4.5: Statistics of ESR in healthy controls and Patients RA

\begin{tabular}{|l||l||c||}
\hline \hline Study groups & ESR Mean \pm S.D gm/dl & p value \\
\hline \hline Healthy control & $10.7 \pm 5.6$ & \multirow{2}{*}{$\mathrm{P} \leq 0.0005$} \\
\hline \hline RA patients & $44.4 \pm 27.2$ & \\
\hline
\end{tabular}

\section{ESR=Erythrocyte Sedimentation Rate SD=Standard Deviation}

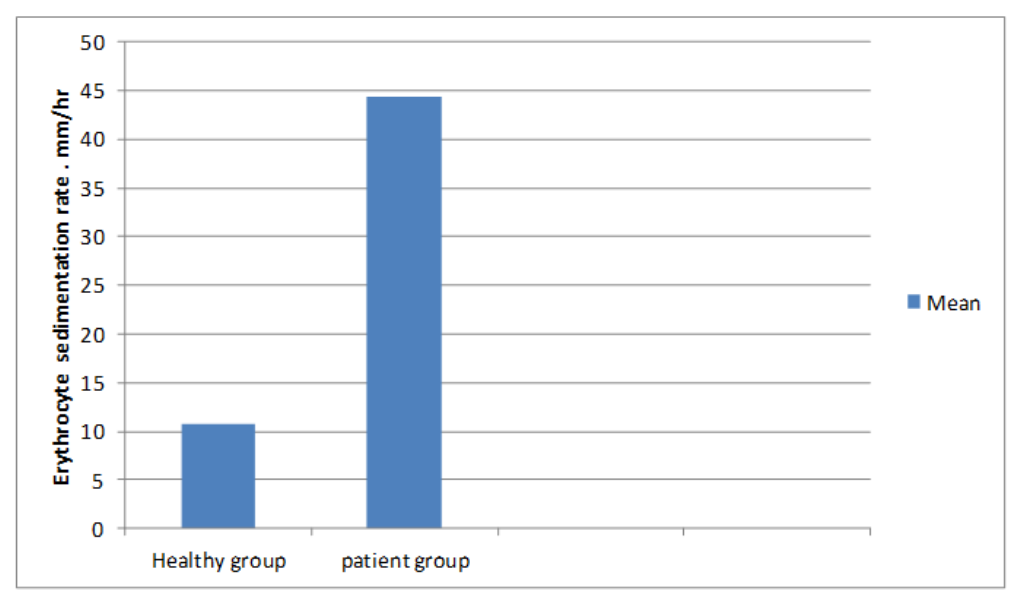

Figure 4.4: Mean \pm SD of ESR in study groups.

The hematological tests have been applied for blood samples of RA and healthy control group. No significant alteration occurs on the mean of WBCs count of RA patients $(9.45 \pm 2.50) 10 \mathrm{e} 3 / \mathrm{uL}$ in comparison with healthy control group $(8.56 \pm 2.41) 10 \mathrm{e} 3 / \mathrm{uL}(\mathrm{P}=0.16)$. table (4.6)

The mean of $\mathrm{Hb}$ is $(12.6 \pm 1.7) \mathrm{gm} / \mathrm{dl}$ for RA patients in comparison with healthy control $(13.8 \pm 1.8)$ $\mathrm{gm} / \mathrm{dl}$ with highly significant differences $(\mathrm{P} \leq 0.01$ for each). table (4.6)

the mean of PCV is $(38.8 \pm 6.6) \%$ for RA patients in comparison with healthy control $(42.9 \pm 5.26) \%$ with significant differences $(\mathrm{P} \leq 0.01$ for each) table (4.6). 
Table (4.6):Mean distribution of serum hematological tests levels among studied groups.

\begin{tabular}{|c|c|c|c|c|c|c|c|}
\hline \multirow[t]{2}{*}{ Hematological tests } & \multirow{2}{*}{$\begin{array}{l}\text { Studied } \\
\text { groups }\end{array}$} & \multirow[t]{2}{*}{$\mathbf{N}$} & \multirow[t]{2}{*}{ Mean } & \multirow[t]{2}{*}{ Std. Deviation } & \multirow{2}{*}{$\begin{array}{l}\text { Std. } \\
\text { Error }\end{array}$} & \multicolumn{2}{|c|}{ Comparison of significant } \\
\hline & & & & & & P-value & Sig. \\
\hline \multirow{3}{*}{$\begin{array}{l}\text { WBC count } \\
{\left[\text { Cell } \times 1^{3}\right]}\end{array}$} & Control & 20 & 8.56 & 2.41 & 0.53 & 0.16 & \\
\hline & RA & 60 & 9.45 & 2.50 & 0.32 & 0.16 & NS \\
\hline & Total & 80 & & & & & \\
\hline \multirow[t]{3}{*}{ PCV\% } & Control & 20 & 42.9 & 5.26 & 1.1 & 0.015 & \\
\hline & $\mathbf{R A}$ & 60 & 38.8 & 6.6 & 0.86 & 0.015 & $\mathbf{S}$ \\
\hline & Total & 80 & & & & & \\
\hline \multirow[t]{3}{*}{$\mathrm{Hb} \mathrm{g/dl}$} & Control & 20 & 13.8 & 1.89 & 0.42 & 0.01 & - \\
\hline & $\mathbf{R A}$ & 60 & 12.6 & 1.7 & 0.22 & 0.01 & $\mathbf{S}$ \\
\hline & Total & 80 & & & & & \\
\hline
\end{tabular}

All the previous studies denoted with the present results on among this study which is explained by the fact that all our patients has early rheumatoid arthritis with early disease process.

Interestingly, the present study revealed that there is significant differences in the mean serum level of IL17 between early RA patients $(8.6 \pm 7.6) \mathrm{pg} \backslash \mathrm{ml}$ and healthy control $(5.3 \pm 3.8) \mathrm{pg} / \mathrm{ml} . \mathrm{P} \leq 0.05$, table 4.7 and figure 4.5

Table 4.7:Descriptive statistics of serum IL-17A between RA groups and healthy control group.

\begin{tabular}{|l|l|l|l|}
\hline Serum level of IL-17 & Healthy control $(\mathbf{p g} / \mathbf{m l})$ & RA Groups $(\mathbf{p g} / \mathbf{m l})$ & P -value \\
\cline { 1 - 3 } Mean & 5.3 & 8.6 & \multirow{2}{*}{ P $\leq 0.05$} \\
\cline { 1 - 3 } S.D. & 3.8 & 7.6 & \\
\cline { 1 - 3 }
\end{tabular}

Healthy control . RA Group ( $p$ value $\leq \mathbf{0 . 0 5})$.

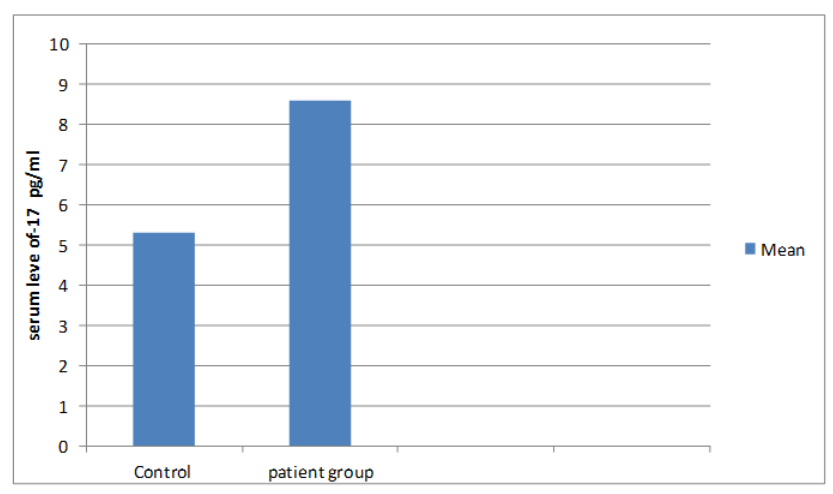

Figure 4.5: Mean value of serum IL-17 in study groups.

This study, serum Zinc levels was significantly lower (ranges from 60-88 mg/L, mean value 74.4 $\pm 7.1 \mathrm{mg} / \mathrm{L}$ ). than in healthy controls' ranges from $(87-123 \mathrm{mg} / \mathrm{L}$, mean value $98.4 \pm 9.1 \mathrm{mg} / \mathrm{L}$ ) ( $\mathrm{p}<0.005)$. The serum Copper level was significantly higher in early RA patient (ranges from 137-215 mg/L, mean value 172.1 \pm 19.1 $\mathrm{mg} / \mathrm{L}$ ). than is level in healthy control group (ranges from $105-150 \mathrm{mg} / \mathrm{L}$, mean value $125.1 \pm 11.6 \mathrm{mg} / \mathrm{L})(\mathrm{p}<$ $0.005)$. In patients with early RA, the mean level of serum $(\mathrm{Mg})$ was significant lowar $(1.2 \pm 0.13 \mathrm{mg} / \mathrm{L})$. as compared with healthy control group mean value $(1.6 \pm 0.19 \mathrm{mg} / \mathrm{L})(\mathrm{p}$ value $<0.0005)$. Table $(4.8)$ Figure 4.6

Table ( 4.8):Serum trace elements concentration in patients with eraly RA and healthy control (mg/ml).

\begin{tabular}{|c|c|c|c|c|}
\hline Trace elements & Studied group & No. & Mean $(\mathrm{mg} / \mathrm{ml}) \pm \mathrm{SD}$ & \multirow{2}{*}{ P-value } \\
\hline \multirow{2}{*}{$\mathbf{Z n}$} & Control & 20 & $98.4 \pm 9.1$ & \multirow{2}{*}{$\mathbf{0 . 0 0 0 5}$} \\
\cline { 2 - 4 } & patients & 60 & $74.4 \pm 7.1$ & \multirow{2}{*}{0.0005} \\
\cline { 2 - 4 } $\mathbf{*} \mathbf{C u}$ & Control & 20 & $125 \pm 11.6$ & \\
\cline { 2 - 4 } & patients & 60 & $172.1 \pm 19.1$ & \multirow{2}{*}{0.0005} \\
\cline { 2 - 5 } & Control & 20 & $1.6 \pm 0.19$ & \\
\hline
\end{tabular}

*Concentration are expressed as mean \pm SD

$\mathrm{Zn}=$ Zinc $\quad \mathrm{Cu}=$ Copper $\quad \mathrm{Mg}=$ Magnesium $\quad \mathrm{SD}=$ Stander Deviation 


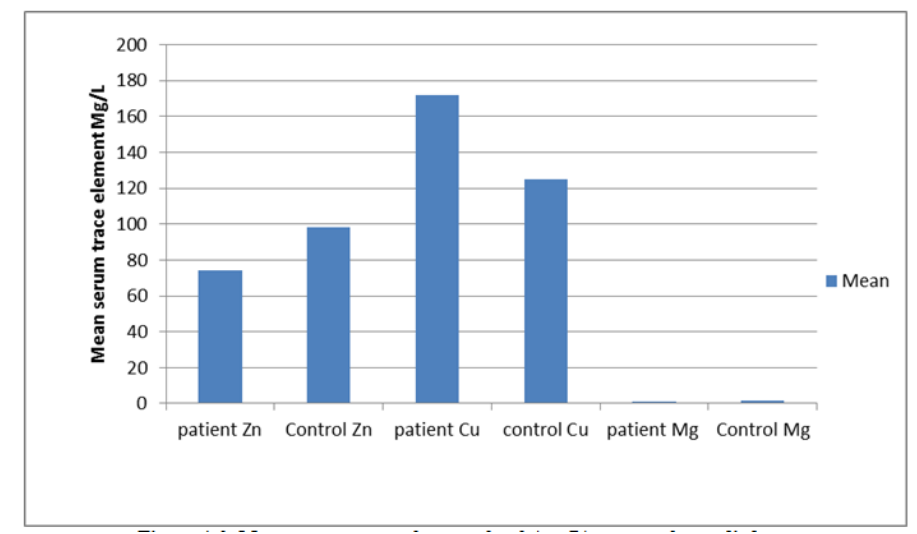

Figure 4.6: Mean serum trace elements level $(\mathrm{mg} / \mathrm{L})$ among the studied groups.

$$
\mathrm{Zn}=\text { Zinc } \quad \mathrm{Cu}=\text { Copper } \quad \mathrm{Mg}=\text { Magnesium }
$$

Table 4.9 revealed the correlation between different parameters studied in this work as seen. The present study showed significant inverse relationship between ( WBC) and (B M I) $\mathrm{p} \leq 0.02$ as show in table ( 4.9).

The present study showed significant inverse relationship between (ESR ) with other parameters $\mathrm{Hb}$ and PCV and IL-17A and Zn p value $\leq\{(0.000)(0.04),(0.03),(0.03)\}$ respectively as show in table (4.9).

The present study showed significant inverse relationship between $(\mathrm{Cu})$ with other parameters $(\mathrm{Hb})$ and $(\mathrm{pcv})$ and $\mathrm{Zn} \mathrm{p}$ value $\leq\{(0.02),(0.02),(0.000)\}$ respectively as show in table (4.9). While there was no correlation between Mg with other parameter( ESR , IL-17A, WBC ,Hb PCV, BMI, Zn, Cu, Age) P >0.05

Table 4.9: Generally strong correlation was found between Interleukin-17A and each of (Age, ESR, Zn) $\mathrm{P}<0.0005$ and $\mathrm{P} \leq 0.03$ and $\mathrm{P} \leq 0.009$ respectively. While there was no correlation between Interleukin-17with other parameters (WBC, $\mathrm{Hb}, \mathrm{PCV}, \mathrm{BMI}, \mathrm{Cu}, \mathrm{Mg}) . \mathrm{P}>(0.1),(0.3),(0.9),(0.3),(0.07),(0.6)$, respectively

Table 4.9:Correlation Coefficient among Different Parameters in early RA Case

\begin{tabular}{|c|c|c|c|c|c|c|c|c|c|c|c|}
\hline & Parameters & Age & ESR & WBC & $\mathrm{Hb}$ & PCV & BMI & IL17 & $\mathrm{Zn}$ & $\mathrm{Cu}$ & $\mathrm{Mg}$ \\
\hline \multirow[t]{2}{*}{ Age } & $\mathrm{r}$ & 1 & $.377^{* *}$ & $-.097-$ & $-.016-$ & $-.048-$ & $-.033-$ & $-.473^{* *}$ & $-.044-$ & .088 & .167 \\
\hline & Sig. (2-tailed) & & .003 & .460 & .903 & .718 & .801 & .000 & .737 & .502 & .201 \\
\hline \multirow[t]{2}{*}{ ESR } & $\mathrm{r}$ & $.377^{* * *}$ & 1 & $-.340-^{* *}$ & $-.532-{ }^{* *}$ & $-.372-^{* *}$ & .104 & $-.268-{ }^{*}$ & $-.377_{-}^{* *}$ & $.535^{* *}$ & $-.059-$ \\
\hline & Sig. (2-tailed) & .003 & & .008 & .000 & .004 & .427 & .039 & .003 & .000 & .654 \\
\hline \multirow[t]{2}{*}{ WBC } & $\mathrm{r}$ & -.097- & $-.340-^{* *}$ & 1 & $.434^{* * *}$ & .140 & $-.297-^{*}$ & $-.199-$ & .230 & - $-208-$ & .161 \\
\hline & Sig. (2-tailed) & .460 & .008 & & .001 & .291 & .021 & .128 & .077 & .111 & .220 \\
\hline \multirow[t]{2}{*}{$\mathrm{Hb}$} & $\mathrm{r}$ & $-.016-$ & $-.532-^{* *}$ & $.434^{* *}$ & 1 & $.790^{* * *}$ & $-.194-$ & $-.122-$ & $.300^{*}$ & $-.388^{-* *}$ & .071 \\
\hline & Sig. (2-tailed) & .903 & .000 & .001 & & .000 & .138 & .354 & .020 & .002 & .589 \\
\hline \multirow[t]{2}{*}{ PCV } & $\mathrm{r}$ & $-.048-$ & $-.372-^{* *}$ & .140 & $.790^{* *}$ & 1 & .061 & .007 & .224 & $-.294-^{*}$ & $-.086-$ \\
\hline & Sig. (2-tailed) & .718 & .004 & .291 & .000 & & .645 & .958 & .088 & .024 & .517 \\
\hline \multirow[t]{2}{*}{ BMI } & $\mathrm{r}$ & $-.033-$ & .104 & $-.297-{ }^{*}$ & $-.194-$ & .061 & 1 & .122 & $-.250-$ & .187 & $-.153-$ \\
\hline & Sig. (2-tailed) & .801 & .427 & .021 & .138 & .645 & & .353 & .055 & .152 & .244 \\
\hline \multirow[t]{2}{*}{ IL17 } & $\mathrm{r}$ & $-.473-^{* *}$ & $-.268-{ }^{*}$ & - & $-.122-$ & .007 & .122 & 1 & $.336^{* *}$ & $-.232-$ & $-.069-$ \\
\hline & Sig. (2-tailed) & .000 & .039 & .128 & .354 & .958 & .353 & & .009 & .074 & .601 \\
\hline \multirow[t]{2}{*}{$\mathrm{Zn}$} & $\mathrm{r}$ & -.044- & $-.377_{-}^{* *}$ & .230 & $.300^{*}$ & .224 & $-.250-$ & $.336^{* *}$ & 1 & $-.806-{ }^{* *}$ & .094 \\
\hline & Sig. (2-tailed) & .737 & .003 & .077 & .020 & .088 & .055 & .009 & & .000 & .474 \\
\hline \multirow[t]{2}{*}{$\mathrm{Cu}$} & $\mathrm{r}$ & .088 & $.535^{* *}$ & $-.208-$ & $-.388^{-* *}$ & $-.294-^{*}$ & .187 & $-.232-$ & $-.806^{* *}$ & 1 & $-.042-$ \\
\hline & Sig. (2-tailed) & .502 & .000 & .111 & .002 & .024 & .152 & .074 & .000 & & .749 \\
\hline \multirow[t]{2}{*}{$M g$} & $\mathrm{r}$ & .167 & -.059- & .161 & .071 & $-.086-$ & $-.153-$ & $-.069-$ & .094 & $-.042-$ & 1 \\
\hline & Sig. (2-tailed) & .201 & .654 & .220 & .589 & .517 & .244 & .601 & .474 & .749 & \\
\hline
\end{tabular}

**. Correlation is significant at the 0.01 level (2-tailed).

*. Correlation is significant at the 0.05 level (2-tailed). 


\section{Discussion.}

Generally this study showed that the prevalence of RA among females was (80\%). This frequency is comparable to some extent with that of local previous studies in Iraq (79.7\%) [14], (76.7\%) [ 15 ], (74.3\%) [16] and that for North American families (76.8\%) [ 17].The above results denoted high frequency among females rather than males which may be due to hormonal differences between them and in turn, their effect on the immune responses. Those make women tend to mount more robust Immune Response (IRs) and these responses tend to be more Th1-like responses rather than Th2 responses, which are triggers of autoantibody formation, hence may enhance the development of autoimmunity [18]. The female to male ratio was 4:1 which is nearly comparable to that for local previous study (3.9:1) [ [ 15] and (3.3:1, 3.4:1) for abroad studies (15)]. These variations may be due to sample size in addition to different circumstances and times beside different population. The mean age of RA patients was observed to be at the fourth decade $(39.3 \pm 9.01)$ years which is higher than that for local previous study $(38.43 \pm 8.28)$ [ 14 ], while it was lower than that of other studies $[(19),(20),(21)]$ which referred to $(47 \pm 12.7)$ years for Colombian RA women, (49 \pm 2.5$)$ among Spanish patients, and (51.3 \pm 8.5$)$ for French RA patients respectively. The lower mean of age probably is due to the fact that the life spans of Iraqi are lower than that for European Further more, the age of disease onset is too younger than that for a broad studies which were $(42.5,41,40.8$ years) as had pointed by $[22)(23)(24)]$. Since the mean of Iraqi age was lower than other so the mean of age of disease onset will be lower too.The hematological tests have been applied for blood samples of RA and healthy control group. No significant alteration occurs on the mean of WBCs count of RA patients $(9.45 \pm 2.50) 10 \mathrm{e} 3 / \mathrm{uL}$ in comparison with healthy control group $(8.56 \pm$ 2.41) $10 \mathrm{e} 3 / \mathrm{uL}(\mathrm{P}=0.16$ ). table (4.7). Regarding WBCs count, the results showed that there is no significance between RA patients and control group; though there is slightly elevation in the WBCs' count of RA patients.. These results are similar to the others $[(15)(16)]$. Serum IL-17A Level The current results denoted that IL-17 A levels were significantly The highest levels in serum of early RA patients when compared to healthy control group addition the increased serum levels of IL-17 in RA patients correlated with ESR,Age,Zn. This finding in agreement with studies stated that IL-17A is highly expressed in the inflammatory joint and drives disease activity, implicating it as a key cytokine and potential therapeutic target. This finding in agreement with studies ( 25). These studies have shown that IL-17A not only drives the proinflammatory response but also enhances the effect of TNF $\alpha$ promoting increased destruction in the RA joint (26), ( 27) One hypothesis mentioned that a decreased Zinc and increase of Copper in sera of acute or chronic inflammatory processes cause an accumulation of Copper and Zinc in many body compartments and in the inflamed areas(8) Supporting the hypothesis that the development of inflammation induces an increase body requirement of Copper and Zinc. The results obtained for Zinc concentrations in healthy and patients group which are shown in table (4.9) show significant difference in Zinc levels $\quad(\mathrm{p}<0.0005)$. Concentration of Zinc is so low in patients group as compared with those in control group. The result obtained in this study are similar to those published in the literature (8).(28) (29) ) Zinc deficiency is common and there are two effect of Copper deficiency on Iron metabolism, the first which occurring early is an adverse effect on Iron absorption (or mobilization), the second was inadequate erythropoiesis, even in the presence of a abundant Iron stores.

The serum Copper level was significantly higher in early RA patient ( mean value $172.1 \pm 19.1 \mathrm{mg} / \mathrm{L}$ ). Than is level in healthy control group mean value $(125.1 \pm 11.6 \mathrm{mg} / \mathrm{L}),(\mathrm{p}<0.005)$. The results of this study indicate that Copper serum level increase significantly during early rheumatoid arthritis these results are in agreement with other studies ) (7)( 13) .protects cells from oxidative damage ( 8)). and results are in disagreement with other studies (30) In this study $\mathrm{Cu}$ level was higher in early RA patient compared with healthy control group this is explained by the small patient sample. The concentration of intracellular Magnesium is very high as compared with concentration of extracellular Magnesium for that reason can be attributed the increase in the output cell concentration to the damage done to the cells and then increase its concentration in the blood serum(10)(11). Magnesium an important in bone structure. Deficiency results in tetany and can lead to calcium deficiency. Magnesium is essential to maintain both acid- base balance in the body, and healthy functioning of nerves and muscles(31). Diets that provide recommended levels of Magnesium are beneficial for bone health, but further investigation on the role of Magnesium in bone metabolism and osteoporosis is needed (28), The decrease of Magnesium level was statistically significant $(\mathrm{p}<0.0005)$. The results of this study indicate that Magnesium serum level decrease significantly during early rheumatoid arthritis these results are in agreement with other studies . (32) ). And results are in disagreement with other studies (30). In this study $\mathrm{Mg}$ level was low in early RA patient compared with healthy control group this is explained by the small patient sample.

\section{Conclusion}

The present study reached the following conclusions

1- Interleukin-17 (IL17A) may has a key role in early Rheumatoid Arthritis inflammatory process. 
2. Morning stiffness, joint swelling and fever are the main clinical features $(100 \%, 85 \%$ and $80 \%$ respectively) which were noticed among RA patients.

3. Interleukin-17A recognized to associate with morning stiffness .

4. The results observed that the levels of serum Zinc, Magnesium were significantly low in patients with early Rheumatoid arthritis as compared healthy control group.

5. In early Rheumatoid arthritis patients ,the level of serum Copper were highly increased in the patients. .

\section{References}

[1]. Murphy G, and Nagase H, Reappraising metalloproteinases in rheumatoid arthritis and osteoarthritis: destruction or repair? Nat Clin Pract Rheumatol; 2008; 4: 128-35.

[2]. Chabaud M, Durand JM, Buchs N, Fossiez F, Page G, Frappart L and Miossec P: Human interleukin-17: a T-cell derived proinflammatory cytokine produced by the rheumatoid synovium. Arthritis Rheum; ( 1999) 42: 963-970.

[3]. Miossec P, Interleukin-17 in fashion, at last: ten years after its description, its cellular source has been identified. Arthritis Rheum; 2007; 56: 2111-2115.

[4]. Lubberts E, Koenders MI and Berg WB. The role of T-cell interleukin-17 in conducting destructive arthritis: lessons from animal models. Arthritis Research \& Therapy.2005; 7(1):29-27.

[5]. Florianczyk B. "Trace elements as constituents of antioxidative proteins", Journal of pre-clinical and clinical research 2008; 2(1): 25-27.

[6]. Rink L and Haase H. "Zinc homeostasis and immunity", trends in immunology 2006; 28(1):1-4.

[7]. Ala S, shokrzadeh M, Pur shoja AM and Saravi SSS "Zinc and Copper plasma concentrations in Rheumatoid Arthritis patients from a selected population in Iran" Pakistan Journal of biological sciences 2009; 12(14): 1041-1044.

[8]. Colak M, Bingol NK, Ayhan O and Avci S, "Serum Copper, Zinc and Selenium levels in Rheumatoid Arthritis" Rhomatizma 2001; 16(2):66-71.

[9]. Satish KT and Reshu M, "Assessment of mineral status ( $\mathrm{Zn}, \mathrm{Cu}, \mathrm{Mg}$ and $\mathrm{Mn}$ ) in Rheumatoid Arthritis patients in Chandigarh, India”, Rheumatology Report 2009,1(5):16-20.

[10]. Michael LB, Edward PF and Larry GS, "Clinical Chemistry" Lippincott William and Wilkins 2010, 403-668.

[11]. Thomas MD, "Textbook of Biochemistry", 7th ed. John and Wiley 2011, 1078-1097.

[12]. Lengman M. "safe upper levels for vitamins and minerals Expert group on vitamins and minerals" Biological Trace Element Research Humana Press Inc 2003;68:137-42.

[13]. Satish KT and Reshu M, "Assessment of mineral status ( $\mathrm{Zn}, \mathrm{Cu}, \mathrm{Mg}$ and $\mathrm{Mn}$ ) in Rheumatoid Arthritis patients in Chandigarh, India”, Rheumatology Report 2009,1(5):16-20.

[14]. Hasaneen KH." Correlation between Rheumatoid Arthritis and some Cytokines among Iraqi Rheumatoid Arthritis patients." M. Sc. Thesis submitted to the collage of Health and Medical Technology 2007; 15:435-9.

[15]. Al-Haidary BA. "HLA-Typing for Iraqi Rheumatoid Arthritis Patients (Familial Profile)." PhD thesis submitted to the College of Medicine / University of Baghdad 2004; 68:137-42.

[16]. Abbas, N.R. "Study some serological parameters among rheumatoid arthritis Iraqi patients." M. Sc. Thesis submitted for the Collage of Medicine /University of Baghdad.2003; 4: 36-6

[17]. Jawaheer D \& Other 28 "Screening the Genom for Rheumatoid Arthritis Susceptibility Genes: A Replication Study and Combined Analysis of 512 Multicase families." Arthritis Rheum. 2003;48(4): 906-16.

[18]. Goldsby RA, Kindt TS \& Oaborne BA. "Autoimmunity". In: "Kuby immunology.” 4th Ed, Freeman W.H. \& Company, NY. 2000; 497-516.

[19]. Anaya JM, Correa PA, Mantilla RD \& Arcos-Burgous M." Rheumatoid Arthritis association in Colombian population in restricted to HLA-DRB1*04QRRAA alleles." Gene Immune .2002; 3: 56-8.

[20]. Pascual M, Nieto A, Lopez-Nevot MA, Ramal L, Maatran L, et al., "Rheumatoid Arthritis in southern Spain: Toward Elucidation of unifying role of HLA class II region in disease predisposition." Arthritis Rheum. 2001;44(2): 307-14.

[21]. Kerlan-Candon S, Louis-Plence P, Widemann A, Combe B, et al., "Specific over-expression of Rheumatoid Arthritis-associated HLA-DR alleles \& presentation of low affinity peptides". Arthritis Rheum. 2001;44 (6): 1281-92.

[22]. Timofeev VT, Shostack NA, Logionova TK, Muradiants AA, Shvyreva NM \& Dunaevea IuV. "Immunological Aspects of early stage of Rheumatoid Arthritis diagnosis." Ter. Arkh. 2000;72(5): 19-21.

[23]. Kwoh CK, Venglish C, Lynn AH, Whitley DM, Young E, \& Chakavarti A. "Age, sex and the familial risk of rheumatoid arthritis". Am. J. Epidemiol. 1996;144 (1): 15-24.

[24]. Gran GT \& Nordvag BY. "Referrals from general practice to an out- patient rheumatology clinic; Disease spectrum and analysis of referral letters." Clin. Rheumatol.2000;19 (6):450-4.

[25]. Miletić .M, Stojanović, R . Pajić O, Bugarski. D **, Mojsilović.S, Čokić .V \& P. Milenković ( Serum interleukin-17 \& nitric oxide levels in patients with primary Sjögren`s syndrome). Indian J Med Res. 2012; 135: 513-519.

[26]. Moran E M, Mullan R, McCormick J, Connolly M, Sullivan O, FitzGerald O, Bresnihan B, Veale BC and Fearon U, Human rheumatoid arthritis tissue production of IL-17A drives matrix and cartilage degradation: synergy with tumour necrosis factor- $\alpha$, Oncostatin M and response to biologic therapies. Arthritis Research \& Therapy. 2009; 11: 113.

[27]. Moran EM, Heydrich R, Ng CT, Saber TP and McCormick J et al., IL-17A Expression Is Localised to Both Mononuclear and Polymorphonuclear Synovial Cell Infiltrates. 2011; 3:8-12

[28]. Satish KT and Reshu M, "Assessment of mineral status ( $\mathrm{Zn}, \mathrm{Cu}, \mathrm{Mg}$ and $\mathrm{Mn}$ ) in Rheumatoid Arthritis patients in Chandigarh, India”, Rheumatology Report 2009;1(5):16-20.

[29]. Carl AB and Edward RA “Tietz Fundamentals of Clinical Chemistry”, 6th Ed., Saunders an imprint of Elsevier 2008; 496-507.

[30]. (Huda M. Ali* and Mohammed A. Al-Zubaidi**,(Evaluation of Trace Elements in Iraqi Patients with Rheumatoid Arthritis by using Atomic Absorption Spectrophotometer (AAS) rheumatoid arthritis Iraqi J Pharm Sci. 2012; 18(2):135-40.

[31]. Lengman M. "safe upper levels for vitamins and minerals Expert group on vitamins and minerals" 2003; 164-287.

[32]. Cojocaru Manole1,3, Cojocaru Inimioara Mihaela2, Marinescu Lucia3, Silosi Isabela4,Ghinescu Minerva ( changes of serum magnesium levels in patients with rheumatoid arthritis stage i-ii before treatment) med con june 2011; 6( 2): 9-16. 